\title{
An evaluation on the analysis of communication faculties and education system compliance with new communication technologies in Turkey
}

\author{
Barış Bulunmaz ${ }^{1 \mathrm{a}}$ \\ ${ }^{1}$ Üsküdar University, Media and Communication Systems Department, Istanbul, Turkey
}

\begin{abstract}
One of the disciplines covered in the social sciences is communication sciences. Communication; when considered from an overall and simple perspective, is defined as the transfer of messages between sender and receiver. As every kind of innovation is integrated into social life over time, increasing human-based practices and significant importance of communication emerge both scientifically and socially; communication has been more institutionalized and gained its current structure. Communication, studied on undergraduate and postgraduate level at many colleges and institutes, has gained even more importance parallel to important changes created by new media and communication technologies especially depending on the spread of Internet and technological infrastructure to a wider area. In this study, a research will be performed with a small group of -in quantitative sense- students, and results will be evaluated about the adaptation of new communication technologies integrated into study of communication and to what extent they are used.
\end{abstract}

Keywords: Social Sciences; Communication Faculties; Education System; New Media; Communication Technologies

\section{Introduction}

When talking about educational activities in the field of social sciences, we are faced with a wide perspective. An extremely wide range of educational activities; from communication to the political science, from psychology to philosophy or from sociology to law are within the coverage area of social sciences. Unlike in applied sciences, where results are based on precise causality or an experimental process; social sciences reach to conclusions based on human relations and human-based evaluations, that enables to make analysis and comments based on the outcomes found in the light of scientific data. Therefore, social sciences along with educational and training activities bring out emerging trends and developments occurring in the field of education; depending both on the variations of a human-based

\footnotetext{
${ }^{a}$ Corresponding author: baris.bulunmaz@uskudar.edu.tr
} 
struggle and requirements caused to adapt to the conditions of the day, but also facing a reality that a continuous change and renewal in itself is a prerequisite. The most important triggers of change and innovation in the social sciences, as always, are research and evaluations based on scientific data. Also, in order to evaluate the scientific data and reach a new information, the three basic underpinnings of science; thesis, antithesis, and synthesis process should be implemented taking validity and reliability into account.

One of the disciplines covered in the social sciences is communication sciences. Communication; when considered from an overall and simple perspective, is defined as the transfer of messages between sender and receiver. When considered in terms of the dimensions of communication, although the definition of the communication requires the presence of at least two individuals, the communication begins with an individual's selfcommunication or inward communication. As an individual's self-communication works out healthy and properly then the communication with the external environment develops in a positive way to that extent; since with every application and thought in the process of that self-communication, the individual makes the preliminary preparation for communication with external environment. Furthermore; communication sciences, performing an interdisciplinary study with other disciplines within the social sciences, create a very large space for itself and prepare the ground for a scientific journey.

The study of communication, where in modern sense began in the early twentieth century world-wide and towards the end of the first half of twentieth century in Turkey, began firstly with journalism education that forms the basis of communication education. As every kind of innovation is integrated into social life over time, increasing human-based practices and significant importance of communication emerge both scientifically and socially; communication has been more institutionalized and gained its current structure. Communication, studied on undergraduate and postgraduate level at many colleges and institutes, has gained even more importance parallel to important changes created by new media and communication technologies especially depending on the spread of Internet and technological infrastructure to a wider area. Consequently, structural changes on theoretical sense have been carried out for the education at Communication Faculties; causing both opening of new departments and applied programs and also bringing education and training activities in line with today's information and technology age.

In this study, firstly some information will be given about communication sciences, communication education and faculties of communication in Turkey. Then evaluations will be made about the reflections of new media and communication technologies on the education of communication and analysis will be made on how combining theoretical and practical study affects the efficiency of communication. Finally, a research will be performed with a small group of -in a quantitative sense- students, and results will be evaluated about the adaptation of new communication technologies integrated into study of communication and to what extent they are used.

\subsection{An overview to communication and communication faculties in Turkey}

The word 'communicate' is historically related to the word 'common'. It stems from the Latin verb communicare, which means 'to share', 'to make common', and which in turn is related to the Latin word for common: communis. When we communicate, we make things common. We thus increase our shared knowledge, our 'common sense' - the basic precondition for all community, [12]. Communication involves an exchange of meaning between a sender and a receiver. Most of time, meanings are exchanged via a code, called language, that can be written or signed, but that is most often spoken. A simple way to differentiate between language and speech is to remember that language is what you say and speech is how you say, [8]. Communication, the sending and receiving of messages, is 
more than just words. It involves both listening and speaking. It can involve words, gestures, facial expressions, and any other ways we express meaning. This effective exchange of thoughts and feelings can be called communication matters, [18]. Communication means conveying messages through one or more modalities; that is, listening, speaking, reading, and writing. We normally think of communication as being between two or more people; however, much of what we 'hear' every day is us talking to ourselves, [7]. Speakers articulate a series of programmed movements to form sequences of sounds that represent words, phrases, and sentences. Then, listeners interpret the message by converting the acoustic energy that reaches their ears into mental representations of words and sentences. Through communication, the individual can influence society at large. At the same time, social and cultural experiences play an important role in shaping the individuals think and communicate, [8].

Communication is a process of transferring information from one entity to another. Communication processes are sign-mediated interactions between at least two agents which share a repertoire of signs and semiotic rules. Communication is commonly defined as 'the imparting or interchange of thoughts, opinions, or information by speech, writing or signs', [13]. Communication is essentially as much a matter of listening as it is of talking and, to be effective, each party must have some understanding each other, [16]. Although communication media have changed drastically as centuries have passed by, communication shows some basic characteristics common to all times, regardless of the size and complexity of the communicating units, and regardless of the distance in time and space between them. Communication is thus a phenomenon basic to all things human. Indeed, in a sense it is common to all living beings, [12]. Communication is never just a conduit, channel, or tool for transferring information. Communication always produces, makes, constructs, [19].

It is generally agreed that we communicate with some purpose in mind and that the most important purpose is to satisfy a personal or social need. Theorists in many disciplines have established the idea that needs are the driving force behind human behaviour. Needs are generally described as requirements of life, which can range from the physical need for food and shelter to the overall sense of wellbeing that is derived from knowing, for instance, that you have achieved success at work or in an examination, [15]. Every communication situation has social dimensions. In your writing at school, the key social relationship usually is that of a student to a teacher. At work, you will have a much wider variety of relationship with your readers, such as manager to subordinate, customer to supplier, or coworker to coworker. Sometimes these relationships will be characterized by cooperation and goodwill. At others, they will be fraught with competitiveness as people strive for recognition, power, or money for themselves and their departments. To write effectively, you will need to attune the style, tone, and overall approach of each communication to these social and political considerations, [1]. In the study of human communication, an umbrella concept embracing mass communication, interpersonal interaction, and intrapersonal communication. The only academic approach primarily concerned with communication in all of its modes is semiotics; however, human communication is a key concept in several disciplines and subdisciplines of the social sciences, including linguistics, sociolinguistics, psycholinguistics, social psychology, anthropology, and sociology, [5].

Because the social scientific study of communication took hold in speech and journalism departments that were then, and still are, dedicated to the inculcation of various communication skills -for example, oratorical and argumentation skills in the case of speech departments and writing and editing skills in the case of journalism departmentsfrom the beginning there was a strong impetus to undertake research addressing practical aims. By using the rapidly developing arsenal of quantitative methods to attack important 
practical research questions, not only could communication skills be better taught to students, but pressing social problems also could be solved by improving communication effectiveness, [3]. Communication Faculties usually had departments such as Journalism, Radio and Television and Public Relations and Advertisement. This classical division within the Communication Faculties continued mostly as it is until today. In recent years some faculties opened departments such as Visual Communications Design, Information and Documents Administration, Visual Arts and Communication Design, Photography and Video, Journalism and Internet Journalism, [17]. Public relations departments in universities all over Turkey have been providing graduate courses and most of their graduates now work in the field, but public relations people cannot have the support of the state for the last two requirements. However, the topic has been debated in Turkey - not only for the graduates of public relations departments, but also for the graduates of Radio, Television and Cinema departments and Journalism departments in Communication Faculties, [10].

As of 2015, there are 46 Faculty of Communication in 27 cities of Turkey. Out of those 46 Faculty of Communication; 16 are under the constitution of foundation universities and 30 are in state universities. These universities/faculties are majorly in İstanbul as well as in the cities of İzmir, Ankara, Aydın, Eskişehir, Antalya, Erzurum, Sivas, Çanakkale, Adana, Kayseri, Elazığ, Gaziantep, Giresun, Gümüşhane, Malatya, Trabzon, Kastamonu, Kocaeli, Mersin, Niğde, Samsun, Denizli, Sakarya, Konya, Isparta and Uşak. İstanbul, İzmir, Ankara and Gaziantep are the cities where more than one university -that hosts a Faculty of Communication within- are located as follows: In İstanbul 3 state and 12 foundation university, in İzmir 1 state and 2 foundation university, in Ankara 2 state and 1 foundation university and in Gaziantep 1 state and 1 foundation university. Rest of the 23 cities host one university each, with a Faculty of Communication, where all of them are state universities.

Besides being a cosmopolitan city and facing immigration from all over Turkey, having more than 15 million population is the primary cause that one-third of Turkey's universities that offers communication education are located in İstanbul. Apart from that, on the whole; considering the increasing competition, special attention to education, increased duration of compulsory education and need for higher education are the facts that increase in the number of universities has reached a significant size, especially in the recent years. However, for Turkey, having a population of over 80 million, this figure cannot still be considered as sufficient. In addition, the issue that needs to be addressed as a priority should be reaching a high level of quality rather than quantity.

When analyzing these 46 Faculty of Communication in Turkey, a total of 22 diverse departments are present, besides from the major departments of Journalism, Public Relations \& Publicity and Radio, Television \& Cinema. These are; Media \& Press, Public Relations \& Advertising, Communication Design \& Management, Cinema \& Television, Photography \& Video, Public Relations, Communication Design, Advertising, New Media, Visual Communication, Television Reporting \& Programming, Communication Sciences, Visual Communication Design, Media \& Communications Systems, Art \& Cultural Management, Media \& Communication, Cinema \& Digital Media, Advertising Design \& Communication and New Media \& Journalism. As seen, department names are mainly derived from three main sections indicated as major departments. Vast majority accept students with central placement, where some of them holds in-house audition.

In the Faculty of Communications, the language of instruction is Turkish in state universities where it is both Turkish \& English in the foundation universities. In foundation universities regular education and distant education are present where state universities offer regular education, second education (night courses) and distant education. Also, foundation universities accept students with full or partial scholarship. 
Additionally, there are Faculty of Communication in each one of the universities in Kazakhstan, Kyrgyzstan and Macedonia as well as 5 universities in T.R.N.C.; that accept students with the central placement exam held in Turkey. Also, 12 universities in Turkey and 2 universities abroad (in Bosnia-Herzegovina and Georgia) that accept students with central exam in Turkey, have some departments for communication under different faculty names.

\subsection{Reflections of new media and communication technologies on the education of communication}

Communication sciences refer to the schools of scientific research of human communication. This perspective follows the logical positivist tradition of inquiry; most modern communication science falls into a tradition of post-positivism. Thus, communication scientists believe that there is an objective and independent reality that can be accessed through the method of scientific enquiry, [13]. Communication technology has had a very strong impact on the nature of scholarly research on human communication. The issues studied by communication scientists over the past forty years have been affected by the nature of communication, [11]. The use of information and communication technologies (ICT) in organizations is a dynamic interaction between the process of technological innovation that leads to new ICT applications and reinvention of existing applications, and the process of organizational innovation that consists of the actual adoption and implementation of an ICT application in an organization, the use of these applications and the effect this has on the work and communication in the organization, [4].

The most widespread understanding of knowledge society is of society as a knowledge economy. A view of knowledge society as a particular economy looks at the way the economy is transformed with knowledge displacing capital and labors as the central element of production. Within this view, the assumption is that new technologies and knowledge workers are essential in the transition from industrial society to knowledge society, [14]. Technologies also condition priorities, define possibilities, set limits on practices, constitute infrastructures and environments, and mediate relationships between people and the nature world, [2].

Telephones were developed in the late 1800s. Radio and television became common in the early 1900s. With the development of computer starting in the $1950 \mathrm{~s}$, communication methods have steadily improved. Today, communication is simple and widespread. Satellites provide a worldwide network of radio, television, and telephone services. We can now communicate with people around the world and even in space within minutes or seconds, [18]. New media is a term meant to encompass the emergence of digital, computerized, often having characteristics of being manipulatable, networkable, dense, compressible, interactive and impartial. Some examples may be the Internet, websites, computer multimedia, computer games, CD-ROMS, and DVDs, [13].

Communication technologies are the nervous system of contemporary society, transmitting and distributing sensory and control information and interconnecting a myriad of interdependent units. These technologies are critical to commerce, essential to entertainment, and intertwined in our interpersonal relationships. Because these technologies are so vitally important, any change in communication technologies has the potential to impact virtually every area of society, [9]. New digital and network technologies have come into the workplace, home and school as major information and communication technologies. This ICT is placing new demands on students, workers and citizens who need to able to communicate and handle information using these new media. The demands include the ability to handle an increasingly diverse and complex range of texts, [6]. Communication technologies play as big a part in our private lives as they do in 
commerce and control in society. Geographic distances are no longer barriers to relationships thanks to the bridging power of communication technologies. We can also entertained and informed in ways that were unimaginable a century ago thanks to these technologies and they continue to evolve and change before our eyes, [9]. Learning environments in schools need to include both traditional environments as well as those characterised by the use of new technologies and more diverse and complex texts. Within this framework it is essential that schools address how to provide students with the necessary skills and understanding to deal with new learning environments and the literacies needed to learn and work effectively within them, [6].

With the development of new media and communication technologies and accessibility over a variety of platforms, significant changes and improvements were recorded for communication training. Thanks to features such as interaction, updatability, renewability, the use of visual elements and multimedia, applicable works and projects emerge as the nature of communications education.

New media tools, that intensively use the advantages provided by the Internet such as smartphones, social media, smart boards, social networking sites, smart TVs; enabled educational function to a more proactive and active structure rather than being reactive and static. Consequently, within the education in Communication Faculties, possibilities to add practical abilities along with theoretical information have increased. Therefore, harmonization of new media and communication technologies with the given education will both allow us to reach a higher quality of education and increase the efficiency.

\subsection{A research on new communication technologies and conclusion}

\subsection{Problem situation}

The spread of the Internet and being integrated with all the infrastructural systems has brought many changes. As we face the new media technologies everywhere and available over a variety of platforms, the education system needs a number of mandatory structural changes. In this context, to what extent new communication technologies are used in the education system appears to be an issue to be evaluated.

\subsection{Objective}

The objective of this study is to conduct a research to figure out the compliance of new communication technologies integrated into education system and the extent of use, and then evaluate the results and make recommendations.

\subsection{Method}

As for the objective of the study mentioned above, a questionnaire will be conducted for 50 students studying in different sections of Üsküdar University Faculty of Communication. Evaluations over the given answers will be made, in order to identify their perception, evaluation and projections towards new communication technologies used in educational activities and to reveal the extent of the problem. Although the sample size is not enough to make generalizations, it is appropriate to do in terms of having an idea and make an assessment.

In this context, as forming the sample of the research, 50 students chosen by random sampling method were applied an 18-question survey using face to face survey method. Besides the demographic characteristics (age, sex, study area, working status) questionnaire is consisted of 18 questions, 5-point Likert scale (strongly 
agree/agree/neutral/disagree/strongly disagree) was used and respondents are asked to answer in means of their level of agreement/disagreement. 18 questions in the survey have not been divided into sections, but were examined on the basis of three categories in the evaluation of research findings and questions are arranged in this way. Namely; the first 6 statements (question) were prepared to identify the instructor's extent of interaction with the new communication technologies, the second- 6 statements are for the location and technical equipment where educational and training activities are held and third- 6 statement were prepared to identify extent of interaction with the new communication technologies for the students who are indeed in the receiver position of educational and training activities.

\subsection{Evaluation of research findings and conclusion}

When we examine the demographic characteristics of the 50 students participated in the study; we see that the most densely age group is the $18-22$ age range with 42 students $(84 \%)$, then comes the age range of $23-28$ with 8 students $(16 \%)$. Out of those students 29 are $(58 \%)$ male and 21 are (42\%) female. 11 students $(22 \%)$ are employed and the rest 39 students $(78 \%)$ are non-employed. In addition, when we examine the departments they study at the Faculty of Communication; 22 students (44\%) study at Media \& Communication Systems, 17 of them (34\%) study at Advertising Design \& Communication and 11 of them $(22 \%)$ study at New Media \& Journalism.

In the survey, students were asked to indicate their level of agreement for the statements in the frame of 5-point Likert scale (strongly agree/agree/neutral/disagree/strongly disagree). In this frame, 50 students participated in the survey responded the statement of "The vast majority of the teaching staff uses new communication technologies in teaching instruction" as follows: 5 students (10\%) strongly agree, 22 students $(44 \%)$ agree, 11 students $(22 \%)$ are neutral, 8 students $(16 \%)$ disagree and 4 students $(8 \%)$ strongly disagree. "The vast majority of the teaching staff is skilled in the use of new communication technologies" statement responded as follows: 3 students $(6 \%)$ strongly agree, 16 students $(32 \%)$ agree, 17 students $(34 \%)$ are neutral, 11 students $(22 \%)$ disagree and 3 students $(6 \%)$ strongly disagree.

"The vast majority of the teaching staff uses new communication technologies in the post-course time" statement responded as follows: 4 students (8\%) strongly agree, 14 students $(28 \%)$ agree, 20 students $(40 \%)$ are neutral, 9 students $(18 \%)$ disagree and 3 students $(6 \%)$ strongly disagree. "Thanks to the new communication technologies, i can ask questions to the vast majority of the teaching staff simultaneously and get information" statement responded as follows: 4 students (8\%) strongly agree, 27 students $(54 \%)$ agree, 12 students $(24 \%)$ are neutral, 6 students (12\%) disagree and 1 student $(2 \%)$ strongly disagree.

"The vast majority of the teaching staff benefit from new communication technologies on the distribution of course notes \& documents" statement responded as follows: 6 students $(12 \%)$ strongly agree, 27 students $(54 \%)$ agree, 7 students $(14 \%)$ are neutral, 7 students $(14 \%)$ disagree and 3 students $(6 \%)$ strongly disagree. "I can also get further information on the academic sense about the majority of the teaching staff, through their personal web pages and social media accounts" statement responded as follows: 4 students (8\%) strongly agree, 20 students (40\%) agree, 12 students (24\%) are neutral, 9 students $(18 \%)$ disagree and 5 students $(10 \%)$ strongly disagree.

"Technical equipment of classrooms, in which education and training activities are held, is high" statement responded as follows: 13 students (26\%) strongly agree, 22 students (44\%) agree, 9 students (18\%) are neutral, 4 students (8\%) disagree and 2 students (4\%) strongly disagree. "There is internet access in classrooms and is working problem- 
free" statement responded as follows: 14 students (28\%) strongly agree, 26 students (52\%) agree, 3 students $(6 \%)$ are neutral, 5 students $(10 \%)$ disagree and 2 students $(4 \%)$ strongly disagree.

"Smart boards are running problem-free" statement responded as follows: 4 students (8\%) strongly agree, 16 students (32\%) agree, 9 students (18\%) are neutral, 16 students (32\%) disagree and 5 students (10\%) strongly disagree. "I can use smart boards also in offcourse time" statement responded as follows: 7 students (14\%) strongly agree, 28 students $(56 \%)$ agree, 5 students $(10 \%)$ are neutral, 6 students (12\%) disagree and 4 students $(8 \%)$ strongly disagree.

"Thanks to the new communication technologies, I can get images located on the smart board right into my phone/smart tab/computer simultaneously" statement responded as follows: 15 students (30\%) strongly agree, 18 students (36\%) agree, 5 students $(10 \%)$ are neutral, 9 students $(18 \%)$ disagree and 3 students $(6 \%)$ strongly disagree. "Thanks to the new communication technologies, I can make instant share through my social media accounts during the course" statement responded as follows: 13 students (26\%) strongly agree, 24 students (48\%) agree, 4 students (8\%) are neutral, 5 students (10\%) disagree and 4 students $(8 \%)$ strongly disagree.

"I'm using new communication technologies in educational and training activities" statement responded as follows: 20 students (40\%) strongly agree, 26 students (52\%) agree, 3 students $(6 \%)$ are neutral and 1 student (2\%) strongly disagrees. "Disagree" option was not chosen by any of the students. "In regard to educational and training activities, I'm using new media technologies in sharing information/image with my friends" statement responded as follows: 25 students (50\%) strongly agree, 24 students $(48 \%)$ agree and 1 student $(2 \%)$ strongly disagrees. "Neutral" and "Disagree" options were not chosen by any of the students.

"In educational and training activities, I think that the use of new communication technologies is indispensable" statement responded as follows: 16 students (32\%) strongly agree, 19 students (38\%) agree, 7 students (14\%) are neutral, 6 students $(12 \%)$ disagree and 2 students (4\%) strongly disagree. "Thanks to the new communication technologies, I believe online education is more useful rather than face to face education" statement responded as follows: 2 students (4\%) strongly agree, 6 students (12\%) agree, 9 students $(18 \%)$ are neutral, 13 students $(26 \%)$ disagree and 20 students $(40 \%)$ strongly disagree.

"Thanks to the new communication technologies, I think online education will be more common in the future" statement responded as follows: 9 students (18\%) strongly agree, 27 students $(54 \%)$ agree, 6 students $(12 \%)$ are neutral, 5 students $(10 \%)$ disagree and 3 students $(6 \%)$ strongly disagree. "Due to the advantages of new communication technologies, I believe that educational and training activities are better quality" statement responded as follows: 4 students $(8 \%)$ strongly agree, 31 students $(62 \%)$ agree, 9 students $(18 \%)$ are neutral, 2 students $(4 \%)$ disagree and 4 students $(8 \%)$ strongly disagree.

Depending on the evaluation of research findings given in detail above, the analysis for research can be concluded as follows. One quarter of the students participated in the survey stated that the interaction of teaching staff with the new communication technologies is low in general. Although one third of the students agree on a positive consensus regarding usage skills, mainly positive views were reported on other issues. In the evaluation of the location and technical equipment where educational and training activities are held, the general view is positive except "the smart boards are running problem-free". When it comes to the issue of the level of their interaction with the new communication technologies; almost all of the students, who are in the receiver position of educational and training activities, approach with a positive outlook and state that -as the users of new communication technologiesthey are aware of its importance and how it takes the education to a better quality. An interesting point is that, although majority of the students think that the benefits of new 
media technologies and online education will be more common in the future, their opinion is that face to face education is more useful than online education.

As a result, depending on the objective of the study to determine the compliance of new communication technologies adapted into educational communication and to what extent will be usable, to bring the following insight and suggestion will be useful: As the interaction of new communication technologies with all the parameters of the education system increase rapidly and intensely, innovations and changes in the use and coordination in educational and training activities will occur. Therefore, besides both accepting and internalizing this change and innovation, acting with the awareness of the people-oriented approach in educational and training activities and without ignoring the fact that both the creator and user are human, it should be accepted that education and human quality is the primary factor in development of a society, approaches and practice models should be developed in order to increase the usage skills of new communication technologies and integration process without eliminating the human factor.

\section{References}

1. Anderson, P. V., Technical communication/A reader-centered approach. Seventh Edition. Boston, MA: Wadsworth, Cengage Learning, (2010).

2. Barney, D., Communication technology. Vancouver, BC: UBC Press, (2011).

3. Berger, C. R., Roloff, M. E. \& Roskos-Ewoldsen, D. R., What is communication science? In Charles R. Berger, Michael E. Roloff \& David R. Roskos-Ewoldsen (Eds.), The handbook of communication science (pp. 3-20). Second Edition. Thousand Oaks, CA: SAGE Publications, (2010).

4. Bouwman, H., Hooff, B. V. D., Wijngaert, L. V. D. \& Dijk, J. V., Information and communication technology in organizations. Thousand Oaks, CA: SAGE Publications, (2005).

5. Chandler, D. \& Munday, R. A, dictionary of media and communication. New York: Oxford University Press, (2011).

6. Downess, T. \& Zammit, K., New literacies for connected learning in global classrooms. In V. S. Subrahmanian \& Satish K. Tripathi (Eds.), Multimedia information systems (pp. 113-128). Norwell, MA: Kluwer Academic Publishers, (2001).

7. Fogle, P. T., Essentials of communication sciences \& disorders. Clifton Park, NY: Delmar, Cengage Learning, (2013).

8. Gillam, R. B. \& Gillam, S. L., An introduction to the discipline of communication sciences and disorders. In Ronald B. Gillam, Thomas P. Marquardt \& Frederick N. Martin (Eds.), Communication sciences and disorders-From science to clinical practice (pp. 3-26). Second Edition. Sudbury, MA: Jones and Bartlett Publishers, (2011).

9. Grant, A. E., Introduction to communication technologies. In August E. Grant \& Jennifer H. Meadows (Eds.), Communication technology update and fundamentals (pp. 1-8). Twelfth Edition. Burlington, MA: Focal Press, (2013).

10. Özden, Z. \& Saran, M., Turkey. In Betteke van Ruler \& Dejan Vercic (Eds.), Public relations and communication management in Europe: A nation-by-nation introduction to public relations theory and practice (pp. 441-458). Berlin: Walter de Gruyter, (2004).

11. Rogers, E. M., Communication technology-The new media in society. New York: The Free Press, (1986).

12. Rosengren, K. E., Communication: An introduction. Thousand Oaks, CA: SAGE Publications, (2000). 
13. Roskos-Ewoldsen, D. R., Handbook of communication science. (Ed.). Second Edition. Cram101 Textbook Reviews, (2014).

14. Saloma-Akpedonu, C., Doing IT in developing societies: Varying contexts, similar epistemic practices. In Raul Pertierra (Ed.), The social construction and usage of communication technologies: Asian and European experiences (pp. 1-19). Quezon City: The University of the Philippines Press, (2007).

15. Steinberg, S., An introduction to communication studies. Cape Town: Juta \& Co., (2007).

16. Stocklmayer, S. M., The background to effective science communication with the public. In Susan M. Stocklmayer, Michael M. Gore \& Chris Bryant (Eds.), Science communication in theory and practice (pp. 3-22). Dordrecht: Kluwer Academic Publishers, (2001).

17. Tılıç, L. D., The Turkish education landscape. In Georgios Terzis (Ed.), European journalism education (pp. 331-344). Chicago, IL: Intellect, The University of Chicago Press, (2009).

18. Wandberg, R., Communication: Creating understanding. Mankato, MN: Capstone Press., (2000).

19. Warren, J. T. \& Fassett, D. L., Communication: A critical/cultural introduction. Thousand Oaks, CA: SAGE Publications, (2011). 